\title{
Small dams also change the benthic macroinvertebrates community in rocky rivers
}

Pequenas barragens também alteram a comunidade de macroinvertebrados bentônicos em rios rochosos

\section{Leticia de Mattos ${ }^{1}$, Larissa Dal Molin $\mathrm{Kruger}^{1}$, Ana Lucia Suriani Affonso ${ }^{1}$, Gilmar Perbiche-Neves ${ }^{2 *}$ and Sidnei Pressinatte Junior ${ }^{1}$}

\author{
${ }^{1}$ Departamento de Ciências Biológicas, Universidade Estadual do Centro Oeste - Unicentro, \\ Rua Simão Camargo Varela de Sá, no 3, Vila Carli, CEP 85040-080, Guarapuava, PR, Brazil \\ ${ }^{2}$ Centro de Ciências da Natureza - CCN, Universidade Federal de São Carlos - UFSCar, Campus \\ Lagoa do Sino, Rodovia Lauri Simões de Barros, km 12, SP-189, Bairro Aracaçú, Buri, SP, Brazil \\ *e-mail: gilmarpneves@yahoo.com.br
}

Cite as: Mattos, L. et al. Small dams also change the benthic macroinvertebrates community in rocky rivers. Acta Limnologica Brasiliensia, 2017, vol. 29, e18.

Abstract: Aim: Here we analyzed some basic ecological attributes (richness and density) of the benthic community in a stretch of a rocky river under the influence of a small dam of a meter in height, forming a small reservoir of run-of-river type. Methods: Sediment samples were taken with a Petersen collector at three different periods and in three sites: upstream from the dam (site 1), close to the dam (site 2) and downstream from the dam (site 3). Organisms were separated in large groups and Chironomidae genera. Results: The particle size analysis indicated that the sites 1 and 2 are dominated by fine sediments, in contrast to site 3 , composed of medium and coarse sediments. A total of 23 taxa of benthic macroinvertebrate groups and 31 genera of Chironomidae were found. Richness and density were different among sampling sites, and for large groups and Chironomidae its attributes increased towards downstream, probably explained by the sediment composition and the originally lotic conditions in site 3, confirmed by all statistical analysis used. In the dam site (2) there was a richness decrease. Non metric multidimensional analysis showed a clear spatial separation of large groups of macroinvertebrates and chironomid genera between sampling sites, indicating that there are typical taxa of each spatial compartment. Canonical correspondence analysis correlated only rubble sediment with the abundance of large groups, and for Chironomidae genera only the granules type was correlationed, with two groups of taxa in the anlysis: one with sites 1 and 2, and other with site 3. Conclusions: Even very small dams in rocky rivers as in the present study alter the environmental variables and ecological attributes of benthic macroinvertebrates.

Keywords: lotic; Brazil; Chironomidae; Jordão River; ecology; sediment.

Resumo: Objetivos: Foram analisados alguns atributos ecológicos básicos (riqueza e densidade) da comunidade bentônica em um trecho de um rio rochoso sob influência de uma pequena barragem de um metro de altura, formando um pequeno reservatório do tipo fio-de-água. Métodos: Amostras de sedimento foram coletadas com draga de Petersen em três períodos e em três pontos: à montante do reservatório (ponto 1), próximo à barragem (ponto 2) e à jusante da barragem (ponto 3). Os organismos foram separados em grandes grupos e gêneros de Chironomidae. Resultados: A análise do sedimento indicou que os pontos 1 e 2 são dominados por sedimentos finos, em contraste do ponto 3, composto por sedimentos médio e grosso. Um total de 23 táxons de macroinvertebrados 
bentônicos e 31 gêneros de Chironomidae foi encontrado. A riqueza e a densidade foram diferentes entre os pontos de amostragem, e para os grandes grupos e Chironomidae esses atritutos aumentaram a jusante, provavelmente devido à composiçáo do sedimento e às condiçôes lóticas originais no ponto 3, confirmados pelas análises estatísticas empregadas. Na regiáo da barragem (ponto 2) houve um decréscimo de riqueza. Análise de escalonamento não-métrico mostrou uma clara separação especial entre os pontos de amostragem, indicando que há táxons típicos de cada compartimento espacial. Análise de correspondência canônica correlacionou apenas cascalho com a abundância dos grandes grupos, e para os gêneros de Chironomidae somente os grânulos foram correlacionados, formando dois grupos na análise: um com os pontos um e dois, e outro com o três. Conclusóes: Mesmo pequenas barragens em rios rochosos como no presente estudo alteram variáveis ambientais e atributos ecológicos de macroinvertebrados bentônicos.

Palavras-chave: lóticos; Brasil; Chironomidae; Rio Jordão; ecologia; sedimento.

\section{Introduction}

Water reservoirs have been constructed since ages ago for water supply, hydropower generation, leisure, fish production, among other uses (Diomande et al., 2013). These environments transform lotic in lentic environments, causing reduction of water flow and more deposition of fine sediment, increase of deep and water transparency, modifying also the physical and chemical conditions and the structure of biological communities (Tundisi, 1986; Palmer et al., 2000). These consequences can be observed in compartments along reservoirs and downstream it dams (Nogueira, 2000, 2001; Mitsuka \& Henry, 2002). Among the several communities of aquatic ecosystems affected by a new lentic environment, the benthic macroinvertebrates show an important tool in recycling nutrients and in the change of energy and mass among trophic levels (Santos et al., 2015). The structure of insect community and other aquatic invertebrates can be modeled in relation to the natural and anthropic changes (Silveira, 2004). They are also an efficient bioindicators due to different tolerances to environmental variables, longer life cycle and low spatial mobility compared to plankton and fishes (Metcalfe, 1989; Queiroz et al., 2008). For example, low dissolved oxygen of reservoirs trend to reduce the richness and diversity of benthic invertebrates, however some species of Chironomidae, Oligochaeta, Bivalvia and Hirudinea can develop high abundances. In contrast, some organisms are typical of environments with good water quality, as nymphs of Plecoptera and Trichoptera larvae (Callisto et al., 2001).

The diversity, resistance and density of macroinvertebrates tend to be affected in the reservoirs (Furey et al., 2006; McEwen \& Butler, 2010; Zhang et al., 2012). Small dams' effects with less than a meter high on the benthic macroinvertebrates are unknown and it is expected to be minimum or absent when compared to large reservoirs. In order to demonstrate the ecological effect of even small size, depth, and very low water retention time reservoirs, this study aimed to detect if even a small dam without lateral expansion in the shape of arms, can significantly alter some basic ecological attributes of benthic macroinvertebrates. In addition, it was sought to test the null hypothesis that the fauna remains unchanged due to the small characteristics above cited. The particle size characteristics of the sediment were related with organisms, seeking help to understand the observed dynamics in the spatial scale.

\section{Material and Methods}

\subsection{Study area}

The Jordão River (Figure 1) is located in the State of Paraná (Brazil), its length is 168 kilometers from its main course to its mouth and is formed by Pedras River and Bananas River, with a total drainage area of $4,730.60 \mathrm{~km}^{2}$. Due to the considerably declivity, many medium and large water reservoirs have been built, mostly for power generation. In this watershed remnants of Araucaria Forest and Natural Fields occur, with a few remnants of semideciduous forest.

For the study, a small reservoir located at the junction of the Pedras and Bananas rivers $\left(25^{\circ} 26^{\prime} 12^{\prime \prime} \mathrm{S}, 51^{\circ} 27^{\prime} 12^{\prime \prime} \mathrm{W}\right)$ was selected, constructed before 1950 decade for wood sawing. This reservoir has only vertical expansion, with about one meter depth in the dam area, and its extension is approximately 650 meters upstream the dam. The dam region is a semi-lentic environment typical of run-of-river reservoirs with very low retention time, which is less than one day (approximately 06 hours). Originally the river bottom was rocky and formed large slabs of basalt, as can be seen in site 3 downstream from the dam. The basaltic 


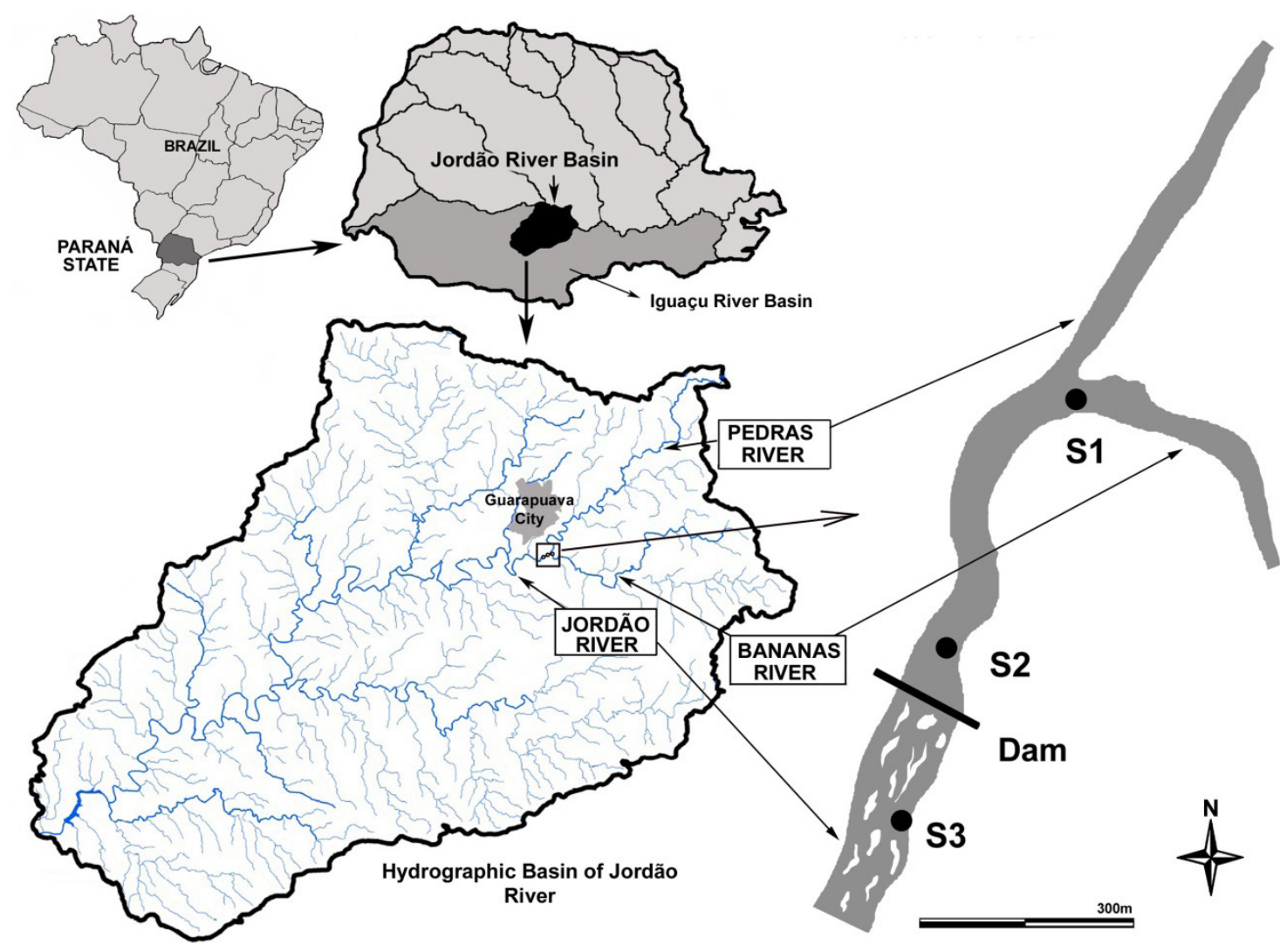

Figure 1. Map of Jordão River basin location and the sampling sites in the Paraná State, Brazil.

environments are quite common in the upper portion of the river.

We selected three sampling points (Figure 1) covering the top upstream zone of the reservoir (site 1 , width $50 \mathrm{~m}$, depth $2 \pm 0.5 \mathrm{~m}$ ), dam region (site 2 , width $75 \mathrm{~m}$, depth $2 \pm 0.5 \mathrm{~m}$ ) and downstream of the dam (site 3, width $200 \mathrm{~m}$, depth $0,40 \pm 0.4 \mathrm{~m}$ ). Samples were collected trimonthly during the year 2012, in the months of May, August and November.

\subsection{Abiotic data}

Rapid assessment protocols were applied in each sampling site, proposed by Hannaford et al. (1997) and EPA (1987) modified by Callisto et al. (2002), to assist the environmental and ecological characterization of the river. Callisto et al. (2002) defines three levels of preservation from the resulting score: 0 to 40 indicate impacted portions; 41-60 points indicate altered sections, and values above 61 points indicate natural extracts.

At each sampling, site sediment samples were collected for analysis of particle size texture, according to Wentworth (1922) and the water temperature was obtained with a mercury thermometer.

\subsection{Biological data}

Triplicate samples of macroinvertebrates were collected at each sampling site with a Petersen collector with an area of $0.02 \mathrm{~m}^{2}$. Samples were taken close to the margin of the river, with depths cited before. The collected material was washed into two screens, with $1.000 \mu \mathrm{m}$ and $250 \mu \mathrm{m}$ mesh opening. The retained material was placed in a plastic pot with $70 \%$ ethanol for further analysis.

Animals found were identified to the lowest possible taxonomic level, based on Pérez (1988) and Higuti \& Franco (2001) for large groups in general, and Wiederholm (1986), Trivinho-Strixino \& Strixino (1995), Epler (2011) and Trivinho-Strixino (2011) for the larvae of chironomids.

\subsection{Data analysis}

In the data analysis the major taxonomic groups of benthic macroinvertebrates were separated into orders, classes and families among these large groups and the family Chironomidae (Diptera: Insecta) has been identified to the genus level. Thus, the analyses were performed with two sets of data. We used analysis of variance (ANOVA) with Tukey HSD test (with p level $<0.05$ ) retrospectively to identify 
possible differences in richness and abundance of taxa between sampling sites.

The non-metric multidimensional scaling analysis (NMDS) was used to obtain spatial ordering of taxa and obtained samples in order to identify horizontal compartments in the reservoir. For this analysis we used a matrix of presence and absence of taxa, using the Bray method, with MASS and Vegan packages for $\mathrm{R}$.

The canonical correspondence analysis (CCA) was performed to check correlations between benthic macroinvertebrates and particle size characteristics, with Vegan package for $\mathrm{R}$ and 1.000 permutations. All statistical analyzes were performed in software R Cran Project v. 3.2.1 (R Development Core Team, 2015).

\section{Results}

\subsection{Particle size characterization and surroundings}

From the protocols, it was observed that there was a higher environmental quality in S3 compared to the other sites, increasing the quality of natural environments (71 points). $S 1$ is recorded in an ambient with conditions of a maintained environment, with 61 points, while S2 has been characterized as a modified environment (47 points).

Regarding the particle size analysis (Figure 2), there were spatial and temporal changes in the reservoir. It was found that in S1, in May, there was highest prevalence of granules $(2-4 \mathrm{~mm})(21 \%)$, but in August and November a greater amount of medium sand prevailed $(0.010-0.020 \mathrm{~mm})$ $(\mathrm{MS})=25 \%$. In S2, in May, there was a greater amount of coarse sand $(0.020-0.039 \mathrm{~mm})$ (CA) (25\%), and in August and September there was a higher prevalence of rubble (major than $256 \mathrm{~mm}$ ) (23\% and 38\%, respectively). In S3 in May lots of rubble were recorded (64\%), in August MS (35\%) prevailed and in November it was CS (28\%), which are the most heterogeneous sediments than in the other sites.

The temperature varied from 13 to $25^{\circ} \mathrm{C}$ throughout the sampled moments. The lowest temperature was registered in May and in November occurred the highest values (Table 1).

\subsection{Macroinvertebrate benthic fauna}

There were recorded 23 taxa of benthic macroinvertebrates and 31 genera of Chironomidae (Table 2).

The highest average value of taxa richness of large groups of macroinvertebrates (Figure 3A)

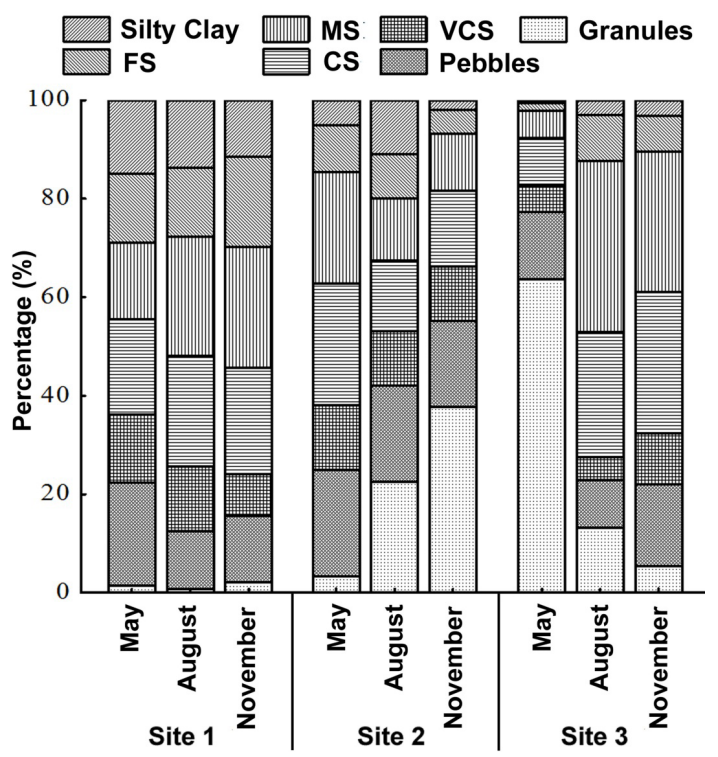

Figure 2. Composition of the granulometry of sampling sites. Very coarse sand (VCS); coarse sand (CS); medium sand (MS) and fine sand (FS). Particles size: silty clay $=3.90-62.5 \mu \mathrm{m}$; finesand $=0.0049-0.010 \mathrm{~mm}$; medium sand $=0.010-0.020 \mathrm{~mm}$; very coarse sand $=1-2 \mathrm{~mm}$; coarse sand $=0.020-0.039 \mathrm{~mm}$; pebbles $=64-256 \mathrm{~mm}$; granules $=2-4 \mathrm{~mm}$.

Table 1. Temperature values $\left({ }^{\circ} \mathrm{C}\right)$ recorded during the moment of the sampling.

\begin{tabular}{cccc}
\hline MONTH & S1 & S2 & S3 \\
\hline May & $13^{\circ} \mathrm{C}$ & $14{ }^{\circ} \mathrm{C}$ & $15^{\circ} \mathrm{C}$ \\
August & $16{ }^{\circ} \mathrm{C}$ & $16{ }^{\circ} \mathrm{C}$ & $17^{\circ} \mathrm{C}$ \\
November & $25^{\circ} \mathrm{C}$ & $23^{\circ} \mathrm{C}$ & $25^{\circ} \mathrm{C}$ \\
\hline
\end{tabular}

and the genera of Chironomidae (Figure 3B), as well as the abundance of these two categories (Figures 3C and 3D), were observed in S3, located downstream of the dam $(\mathrm{F}>3.37, \mathrm{p}<0.05)$. There was an increasing tendency of these two attributes in order in the downstream of the reservoir. Site 3 was similar to S2 (dam region) for both ecological attributes.

In the NMDS for large groups (Figure 4A) the stress was 0.01, and for Chironomidae (Figure 4B) was 0.08 . For both, two convergent solutions analyses were found after an attempt. There was a clear spatial separation of large groups of macroinvertebrates and chironomid genera between sampling sites (Figure 4), indicating that there are typical taxa of each spatial compartment. Among all taxa recorded, the NMDS corroborate the trend indicated by ANOVA in Figure 2, that there is a higher concentration of taxa and genera in site 2 and especially in site 3 . 
The CCA for large groups (Figure 5A) explained $82 \%$ of the variance in the data, and the genera of Chironomidae (Figure 5B) explained $50 \%$ of the data. In general, the spatial distribution pattern followed to that observed in NMDS (Figure 4), with accumulation of taxa at site 3 and with clear separation of the sampling points.

In the CCA for large groups (Figure 5A), only the rubble was significantly correlated to the abundance of taxa $\left(r^{2}=0.91 ; p=0.04\right)$,
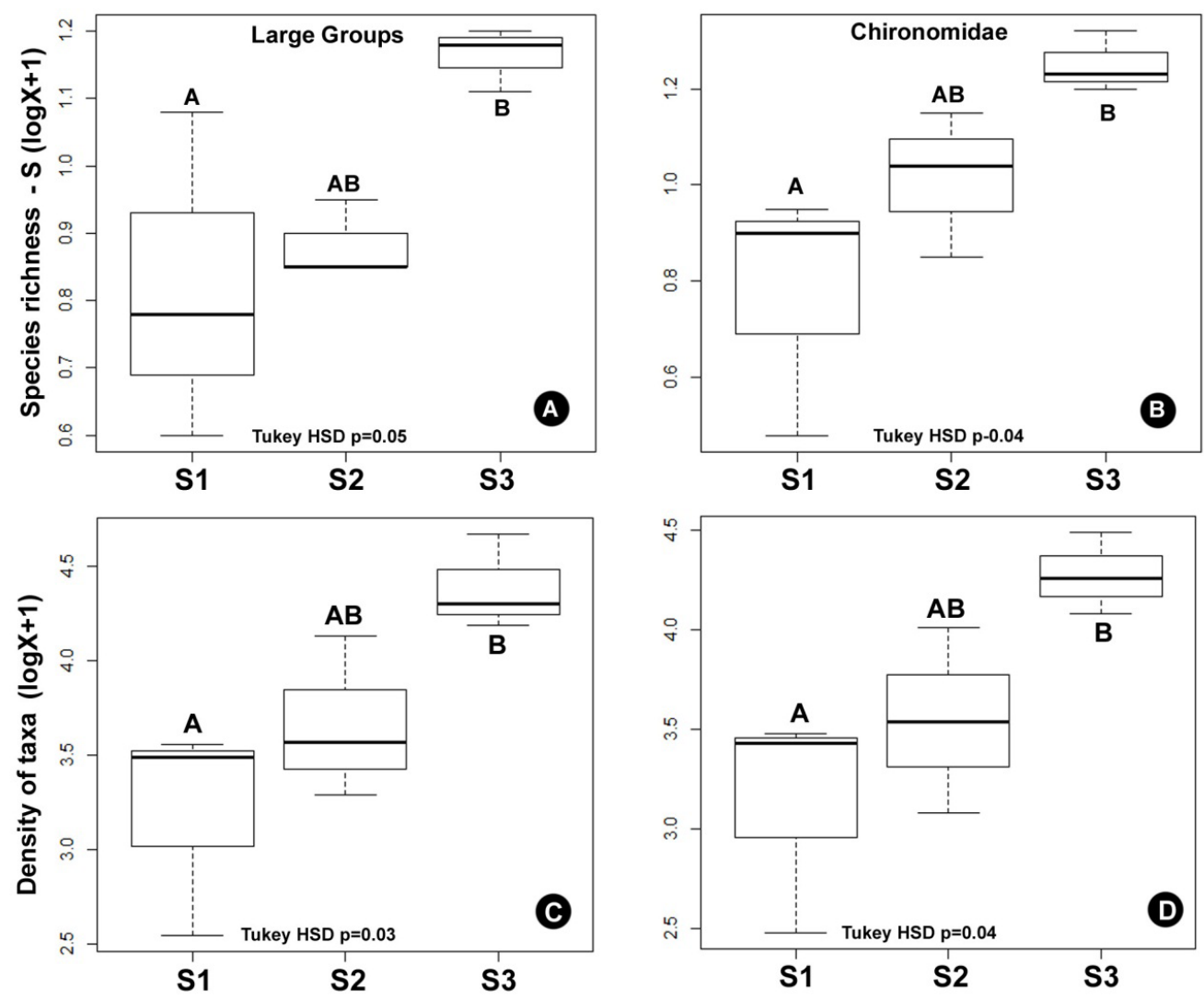

Figure 3. Boxplots in a logarithmic scale indicating significant differences among means comparing the richness and abundance of taxa of large groups $(\mathrm{A}, \mathrm{C})$ and chironomid genera $(\mathrm{B}, \mathrm{D})$ between sampling sites.
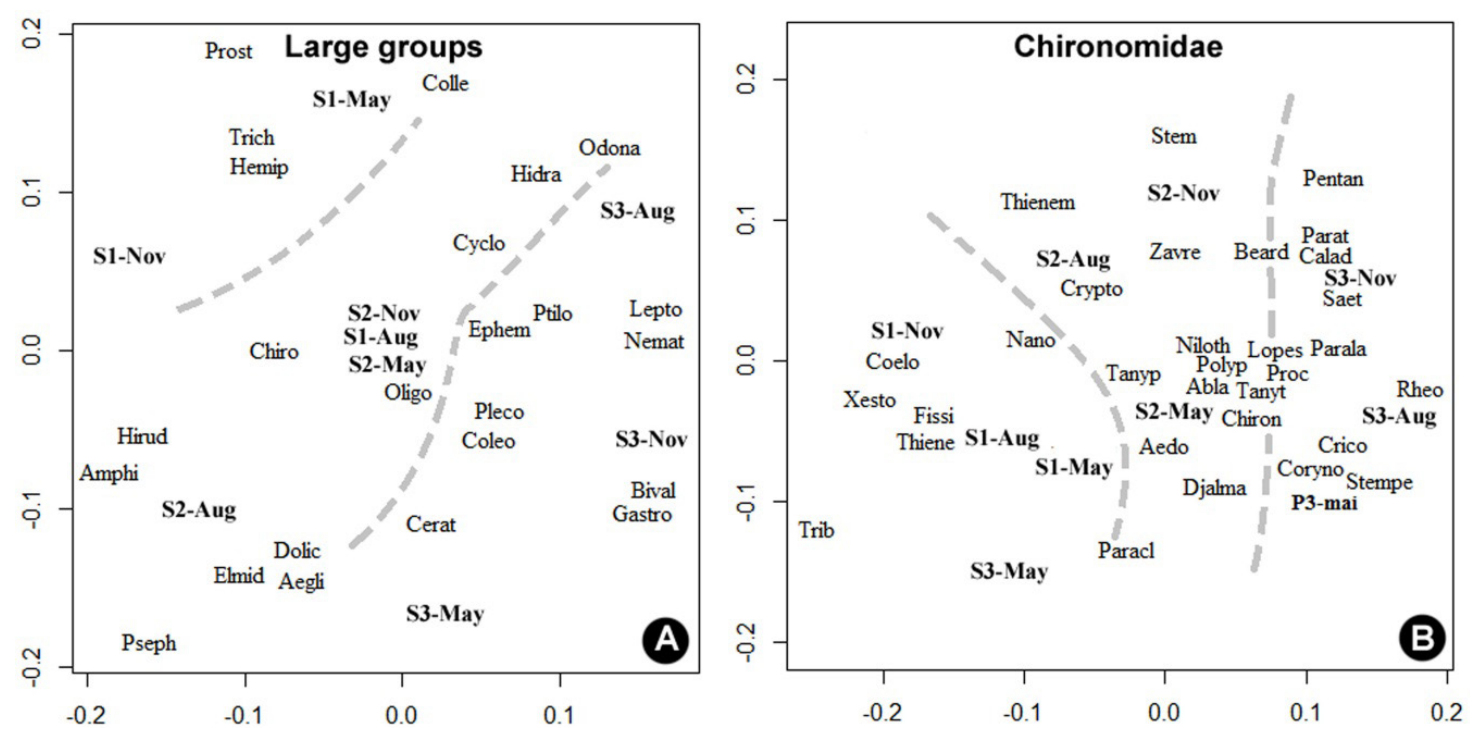

Figure 4. NMDS for spatial ordering of large groups of benthic macroinvertebrates (A) and also of chironomid genera (B). For captions of taxa see Table 2. 
related positively with sites 3 and 2, and Bivalvia, Psephenidae, Amphipoda, Aeglidae, Gastropoda and Hirudinea. Inversely related to these organisms, CCA highlighted the Dolichopodiae, Plecoptera,
Hemiptera, Trichoptera, Odonata, Hidracarina and Leptoceridae.

In another CCA to the genera Chironomidae (Figure 5B), only the granules were correlated
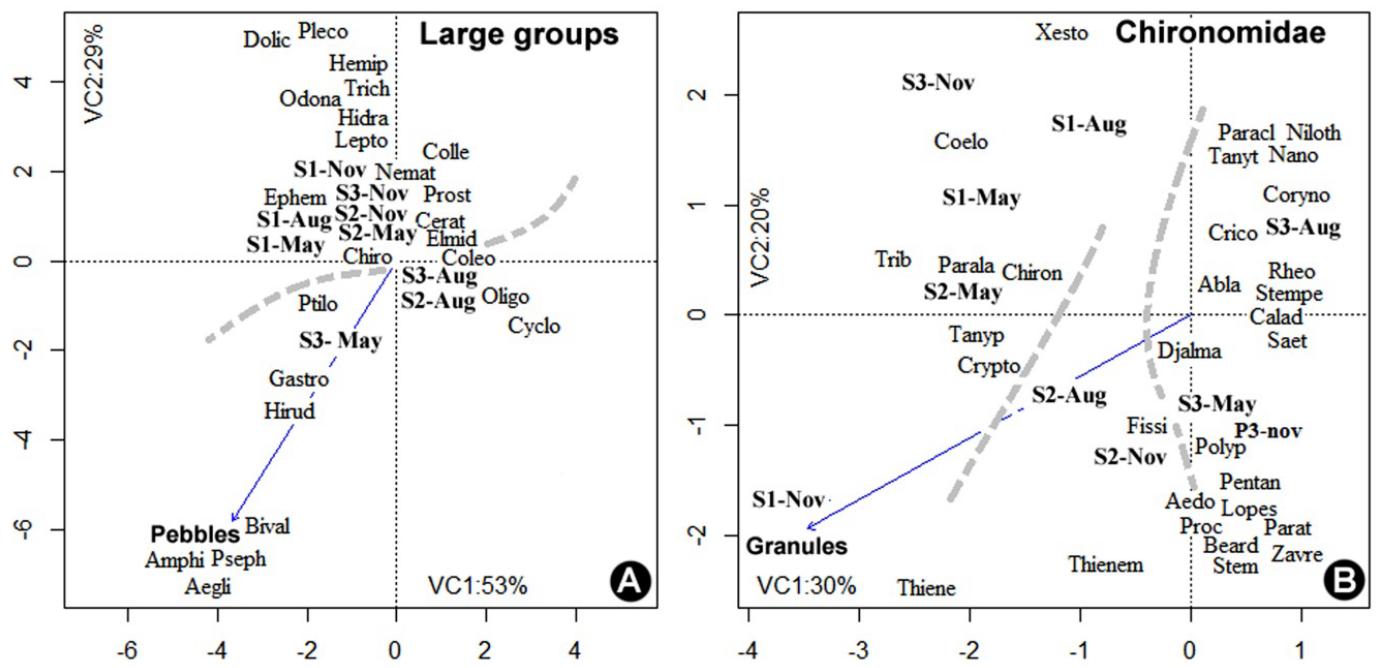

Figure 5. CCA performed to correlate abundances of benthic major groups (A) and Chironomidae (B) with the granulometric data. For captions of taxa see Table 2, and for particle size variables see Figure 2.

Table 2. List of taxa, divided in large groups and Chironomidae genus, collected at three samples sites of the Jordão River (PR), with its abbreviations for posterior statistical analysis.

\begin{tabular}{|c|c|c|c|c|c|c|c|c|c|}
\hline \multirow{2}{*}{ Large groups } & \multirow{2}{*}{ Abbrev. } & \multicolumn{3}{|c|}{ SITES } & \multirow{2}{*}{ Chironomidae (Diptera) } & \multirow{2}{*}{ Abbrev. } & \multicolumn{3}{|c|}{ SITES } \\
\hline & & S1 & S2 & S3 & & & S1 & S2 & S3 \\
\hline Nematoda & Nemat & & & $\mathrm{X}$ & Ablabesmyia sp. & Abla & $\mathrm{X}$ & $\mathrm{X}$ & $\mathrm{X}$ \\
\hline Gastropoda & Gastro & & & $x$ & Aedokritus sp. & Aedo & $x$ & & \\
\hline Bivalvia & Bival & & & $x$ & Beardius sp. & Beard & $\mathrm{X}$ & & $x$ \\
\hline Oligochaeta & Oligo & $x$ & $x$ & $x$ & Caladomyia sp. & Calad & $x$ & $x$ & $x$ \\
\hline Hirudinea & Hirud & $x$ & $x$ & $x$ & Chironomus sp. & Chiron & $x$ & $x$ & \\
\hline Prostigmata & Prost & $x$ & $x$ & $x$ & Coelotanypus sp. & Coelo & & & \\
\hline Hidracarina & Hidra & $x$ & $x$ & $x$ & Corynoneura sp. & Coryno & $x$ & $x$ & \\
\hline Cyclopoida & Cyclo & & & $x$ & Cricotopus sp. & Crico & $x$ & $x$ & $x$ \\
\hline Amphipoda & Amphi & $x$ & & $x$ & Cryptochironomus sp. & Crypto & $\mathrm{X}$ & & \\
\hline Aeglidae & Aegli & & & $x$ & Djalmabatista sp. & Djalma & $\mathrm{X}$ & $x$ & $x$ \\
\hline Collembola & Colle & $x$ & & $x$ & Fissimentum sp. & Fissi & $x$ & & \\
\hline Ephemeroptera & Ephem & $x$ & $x$ & $x$ & Lopescladius sp. & Lopes & $x$ & & \\
\hline Odonata & Odona & $x$ & & $x$ & Nanocladius sp. & Nano & & $x$ & \\
\hline Trichoptera & Trich & $x$ & & & Nilothauma sp. & Niloth & & $x$ & \\
\hline Plecoptera & Pleco & & & $x$ & Paracladius sp. & Paracl & $x$ & $x$ & \\
\hline Ceratopogonidae & Cerat & $x$ & $x$ & $x$ & Paralauterborniella sp. & Parala & $x$ & $x$ & $x$ \\
\hline Elmidae & Elmid & & & $x$ & Paratendipes sp. & Parat & & $x$ & \\
\hline Ptilodactylidae & Ptilo & $x$ & $x$ & $x$ & Pentaneura sp. & Pentan & & $x$ & $x$ \\
\hline Dolichopodiae & Dolic & & & $x$ & Polypedilum sp. & Polyp & $x$ & $x$ & $x$ \\
\hline Leptoceridae & Lepto & & & $x$ & Procladius sp. & Proc & $x$ & & $x$ \\
\hline Coleoptera & Coleo & & $x$ & $x$ & Rheotanytarsus sp. & Rheo & $x$ & $x$ & $x$ \\
\hline Psephenidae & Pseph & & $x$ & $x$ & Saetheria sp. & Saet & & $x$ & $x$ \\
\hline \multirow[t]{9}{*}{ Hemiptera } & Hemip & $x$ & & & Stempellina sp. & Stem & & & $x$ \\
\hline & & & & & Stempellinella sp. & Stempe & $x$ & $x$ & \\
\hline & & & & & Tanypus sp. & Tanyp & & & $x$ \\
\hline & & & & & Tanytarsus sp. & Tanyt & & $x$ & \\
\hline & & & & & Thienemania sp. & Thiene & $x$ & & \\
\hline & & & & & Thienemanniella sp. & Thienem & $x$ & & \\
\hline & & & & & Tribelos sp. & Trib & $x$ & & \\
\hline & & & & & Xestochironomus sp. & Xesto & & $x$ & \\
\hline & & & & & Zavreliella sp. & Zavre & & & $x$ \\
\hline
\end{tabular}


$\left(\mathrm{r}^{2}=0.85 ; \mathrm{p}=0.04\right)$ with those genera, mainly represented by Thienemania and Thienemanniela, and Tanypus, Cryptopus, etc, in sites 1 and 2. On the other hand, a large group of taxa that occurred at site 3 was inversely correlated with taxa associated with the granules. Among this group of genres were included: Nilothauna, Nanocladius, Paracladius, Tanytarsus, Corynoneura, Cricotopus, Rheotanytarsus, Ablablesmya, Stempellinella, Caladomia and Saetheria.

\section{Discussion}

The sampling sites were clearly separated in this study, rejecting the null hypothesis. It was shown that even very small dams cause changes in ecological attributes of benthic macroinvertebrates. Factors such as reduced flow, increased water column (depth) and change in particle size characteristics (due water velocity, flow) influenced these organizations, as highlighted previously (Moretto et al., 2003; Pamplin et al., 2006).

The occurrence of spatial compartments in reservoirs occurs for both limnological variables and biological communities (Nogueira, 2001; Moretto et al., 2003; Pamplin et al., 2006; Pamplin \& Rocha, 2007; Nogueira et al., 2008; Jorcin \& Nogueira, 2008). Depth differences, water flow, size, area and volume of the reservoir, water retention time and human activities in the watershed tend to influence the presence of these spatial compartments.

Strong spatial changes tend to favor the dominance of certain taxa as Oligochaeta, Chironomidae and some Mollusca, which are mainly related to the nutrients, organic matter concentration and particle size characteristics (Pamplin et al., 2006; Jorcin \& Nogueira, 2008). Lentic waters tend to promote the reproduction of algae and zooplankton, and thus the Chironomid finds enough food for their energy needs (Ouattara et al., 2001; Diomande et al., 2013), and so they can become very abundant organisms for tolerating large climate, hydrological and limnological variations (Pamplin et al., 2006; Jorcin \& Nogueira, 2008). As for Oligochaete, many species live in the sediment, feed on debris and decomposing material (Pamplin et al., 2006), with abundant silt and sand (Jorcin \& Nogueira, 2008).

The existence of spatial compartments even in such a small reservoir can justify the longitudinal gradient observed increase of taxa and abundance toward the site 3 , following the direction downstream of the reservoir. The findings add information about the spatial distribution of these organisms in reservoirs, being different, for example, of eutrophic reservoirs in the tropical region (Pamplin et al., 2007).

In this study, site 3 retains the properties of the rock bottom and provides a greater habitat heterogeneity when compared to sites 1 and 2, at the upstream of the reservoir and close to the dam, respectively. In site 3 the sediment was dominated by medium and coarse fractions compared to sites 1 and 2. Site 3 is also a shallower region and exposed to sunlight, which stimulates productivity and can sustain a richer and more abundant benthic community adhered to rocky and thick substrate.

The small dam (site 2) not had small richness, as observed in other reservoirs (all much larger) by Santos \& Henry (2001), Pamplin et al. (2006) and Jorcin \& Nogueira (2008). The small size of the reservoir, the low residence time and the low height of the dam does not provide the decrease in richness in the dam area with ample renewal of particle size characteristics.

The downstream increase trend with higher value of richness and abundance in site 3 can be explained by the heterogeneity of the habitat with the dominance of higher fractions (rubble), since the substrate is the living environment of benthic organisms (Diomande et al., 2013). The dissolved oxygen and depth are also key factors for the distribution of macroinvertebrates (Santos \& Henry, 2001; Shimabukuro \& Henry, 2011). The depth at site 3 is smaller than the other sites. According to Barbosa et al. (2011) shallow regions hosts a most diverse community of macroinvertebrates than deep regions, preferably above occurrence, the availability of food items, and different groups of macroinvertebrates are associated with communities of water plants, and the use of the substrate as safe fixation, transport and reproduction.

The change of particle size texture throughout the sampling period comparing the same sampling sites indicate that the reservoir in question presents constant changes, also associated with the characteristics mentioned above, such as low residence time and small size of the reservoir. The historical rainfall data is high above annual average precipitation $(1,800 \mathrm{~mm}$ annual), with an absence of dry and rainy seasons (Perbiche-Neves et al., 2015). The high rainfall and the morphometric characteristics of the reservoir allow intensive exchange of solids retained in the sediment, explaining the seasonal differences.

Dams smaller than a meter generating small reservoirs of the run-of-river type also alter the 
ecological attributes of macroinvertebrates. However, there is no decrease in richness close to the dam, as observed for larger and deeper reservoirs. The organisms are distributed spatially according to the granulometric characteristics influenced by the reservoir, even if it is small.

\section{References}

BARBOSA, F.F., GODOY, B.S. and OLIVEIRA, L.G. Trichoptera Kirby (Insecta) immature fauna from Rio das Almas Basin and Rio Paranã, Goiás State, Brazil, with new records for some genera. Biota Neotropica, 2011, 11(4), 21-25. http://dx.doi.org/10.1590/ S1676-06032011000400001.

CALlisto, M., FERREIRA, W., MORENO, P., GOUlART, M.D.C. and PETRUCiO, M. Aplicação de um protocolo de avaliação rápida da diversidade de habitats em atividades de ensino e pesquisa (MG-RJ). Acta Limnologica Brasiliensia, 2002, 14(1), 91-98.

CALLISTO, M., GOULART, M. and MORETTI, M. Macroinvertebrados bentônicos como ferramenta para avaliar a saúde de riachos. Revista Brasileira de Recursos Hidricos, 2001, 6(1), 71-82. http://dx.doi. org/10.21168/rbrh.v6n1.p71-82.

DIOMANDE, D., KPAI, N.N., KOUADIO, K.N., COSTA, K.S. and GOURENE, G. Spatial distribution and structure of benthic macroinvertebrates in an artificial reservoir: Taabo Lake (Côte d'Ivoire). International Journal of Biological and Chemical Sciences, 2013, 7(1), 503514.

ENVIRONMENTAL PROTECTION AGENCY EPA. Biological criteria for the protection of aquatic life. Columbus, Ohio: Division of Water Quality Monitoring Assessment, 1987.

EPLER, J.H. Identification manual for the larval chironomidae (Diptera) of North and South Carolina. North Carolina: Department of Environment and Natural Resources, 2011.

FUREY, P.C., NORDIN, R.N. and MAZUMDER, A. Littoral benthic macroinvertebrates under contrasing drawdown in a reservoir and a natural lake. Journal of the North American Benthological Society, 2006, 25(1), 19-31. http://dx.doi.org/10.1899/08873593(2006)25[19:LBMUCD]2.0.CO;2.

HANNAFORD, M.J., BARBOUR, M.T. and RESH, V.H. Training reduces observer variability in visualbased assessments of stream habitat. Journal of the North American Benthological Society, 1997, 16(4), 853-860. http://dx.doi.org/10.2307/1468176.

HIGUTI, J. and FRANCO, G.M.S. Identificação de invertebrados para análise de conteúdo estomacais de peixes. Maringá: UEM, 2001.

JORCIN, A. and NOGUEIRA, M.G. Benthic macroinvertebrates in the Paranapanema reservoir cascade (southeast Brazil). Brazilian Journal of Biology = Revista Brasileira de Biologia, 2008, 68(4), 10131024. Supplement. PMid:19197472. http://dx.doi. org/10.1590/S1519-69842008000500009.

MCEWEN, D.C. and BUTLER, M.G. The effects of water-level manipulation on the benthic invertebrates of a managed reservoir. Freshwater Biology, 2010 , 55(5), 1086-1101. http://dx.doi.org/10.1111/ j.1365-2427.2009.02382.x.

METCALFE, J.L. Biological water quality assessment of running waters based on macroinvertebrate communities: History and present status in Europe. Environmental Pollution, 1989, 60(1-2), 101-139. PMid:15092393. http://dx.doi.org/10.1016/02697491(89)90223-6.

MITSUKA, P.M. and HENRY, R. The fate of copepod populations in the Paranapanema River (São Paulo, Brazil), downstream the Jurumirim Dam. Brazilian Archives of Biology and Technology, 2002, 45(4), 479-490. http://dx.doi.org/10.1590/S151689132002000600012.

MORETTO, Y., HIGUTI, J. and TAKEDA, A.M. Spatial variation of the benthic community in the Corumbá Reservoir, Goiás, Brazil. Acta Scientiarum. Biological Sciences, 2003, 25(1), 23-30.

NOGUEIRA, M.G. Phytoplankton composition, dominance and abundance as indicators of environmental compartmentalization in Jurumirim Reservoir (Paranapanema River), Sáo Paulo Brazil. Hydrobiologia, 2000, 431(2-3), 115-128. http:// dx.doi.org/10.1023/A:1003769408757.

NOGUEIRA, M.G. Zooplankton composition, dominance and abundance as indicators of environmental compartimentalization in Jurumirim Reservoir (Paranapanema River), São Paulo, Brazil. Hydrobiologia, 2001, 455(1-3), 1-18. http://dx.doi. org/10.1023/A:1011946708757.

NOGUEIRA, M.G., REIS-OLIVEIRA, P.C. and BRITTO, Y.T. Zooplankton assemblages (Copepoda and Cladocera) in a cascade of reservoirs of a large tropical river (SE Brazil). Limnetica, 2008, 27(1), 151-170.

OUATTARA, A., PODOOR, N. and GOURÈNE, G. Etudes préliminaires de la distribution spatiotemporelle du phytoplancton dans un système fluvio-lacustre africain (Basin Bia; Côte d'Ivoire). Hydroécologie Appliquée, 2001, 13(1), 113-132. http://dx.doi.org/10.1051/hydro:2001010.

PALMER, T.D., WILlHOITE, A.R. and GAGE, F.H. Vascular niche for adult hippocampal neurogenesis. The Journal of Comparative Neurology, 2000, 425(4), 479-494. PMid:10975875. http://dx.doi.org/10.1002/10969861(20001002)425:4<479::AID-

CNE2>3.0.CO;2-3. 
PAMPLIN, P.A.Z., ALMEIDA, T.C.M. and ROCHA O. Composition and distribution of bentic macroinvertebrates in Americana Reservoir, SP, Brazil. Acta Limnologica Brasiliensia, 2006, 18(2), 121-132.

PAMPLIN, P.A.Z., ALMEIDA, T.C.M. and SILVAFILHO, J.P. New record of Laeonereis acuta (Treadwell, 1923) (Nereididae: Polychaeta) in Northeast coast of Brazil. Biota Neotropica, 2007, 7(3), 353-355. http://dx.doi.org/10.1590/S167606032007000300035 .

PAMPLIN, P.A.Z. and ROCHA, O. Temporal and bathymetric distribution of benthic macroinvertebrates in the Ponte Nova Reservoir, Tietê River (São Paulo, Brazil). Acta Limnologica Brasiliensia, 2007, 18(2), 121-132.

PERBICHE-NEVES, G., BOXSHALL, G.A., PREVIATTELLI, D., NALIATO, D.A.O., PIE, M.R., ROCHA, C.E.F. and NOGUEIRA, M.G. Regulation of the abundance and turnover of copepod species by temperature, turbidity and habitat type in a large river basin. Austral Ecology, 2015, 40(6), 718-725. http://dx.doi.org/10.1111/ aec. 12240 .

PEREZ, G.R. Guia para el estudio de los macroinvertebrados acuaticos. Bogota: Departamento de Antioquia. Universidad de Antioquia, 1988.

QUEIROZ, J.F., SILVA, M.S.G.M. and TRIVINHOSTRIXINO, S. Organismos bentônicos: biomonitoramento de qualidade de águas. Jaguariúna: EMBRAPA, 2008 [viewed 4 Apr. 2016]. Embrapa Meio Ambiente. Available from: http://www.cnpma. embrapa.br/download/LivroBentonicos.pdf

R DEVELOPMENT CORE TEAM. $R$ : A language and environment for statistical computing. Version 2.13 [software]. Vienna: R Foundation for Statistical Computing, 2015 [viewed 4 Apr. 2016]. Available from: https://www.R-project.org/

SANTOS, C.M. and HENRY, R. Composição, distribuição e abundância de Chironomidae (Diptera, Insecta) na Represa de Jurumirim (rio ParanapanamaSP). Acta Limnologica Brasiliensia, 2001, 13(2), 99-115.
SANTOS, N.C.L., SANTANA, H.S., DIAS, R.M., BORGES, H.L.F., MELO, V.F., SEVERI, W., GOMES, L.C. and AGOSTINHO, A.A. Distribution of benthic macroinvertebrates in a tropical reservoir cascade. Hydrobiologia, 2015, 765(1), 265-275. http://dx.doi.org/10.1007/s10750015-2419-6.

SHIMABUKURO, E.M. and HENRY, R. Controlling factors of benthic macroinvertebrates distribution in a small tropical pond, lateral to the Paranapanema River (São Paulo, Brazil). Acta Limnologica Brasiliensia, 2011, 23(2), 154-163. http://dx.doi.org/10.1590/ S2179-975X2011000200006.

SILVEIRA, M.P. Aplicação do biomonitoramento para avaliação da qualidade da água em rios. Jaguariúna: Embrapa Meio Ambiente, 2004. Documentos, 36.

TRIVINHO-STRIXINO, S. and STRIXINO, G. Larvas de Chironomidae (Diptera) do Estado de São Paulo: guia de identificação e diagnose dos gêneros. São Carlos: PPG/ERN/UFSCAR, 1995.

TRIVINHO-STRIXINO, S. Larvas de Chironomidae: guia de identificação. São Carlos: Universidade Federal de São Carlos, 2011.

TUNDISI, J.G. Ambientes, represas e barragens. Ciência Hoje, 1986, 5(27), 48-54.

WENTWORTH, C.K. An escale of grade and class terms for clastic sediments. The Journal of Geology, 1922, 30(5), 377-392. http://dx.doi.org/10.1086/622910.

WIEDERHOLM, T. Chironomidae of the Holartic region: keys and diagnoses. Entomologica Scandinavica Supplement, 1986, 28, 299-456.

ZHANG, M., CAI, Q., XU, Y., KONG, L., TAN, L. and WANG, L. Spatial distribution of macroinvertebrate community along a longitudinal gradient in a eutrophic reservoir-bay during different impoundment stages, China. International Review of Hydrobiology, 2012, 97(3), 169-183. http://dx.doi. org/10.1002/iroh.201111488.

Received: 19 July 2016 Accepted: 13 November 2017 